\title{
水系高濃度アルミナスラリーの分散特性 ${ }^{\dagger}$

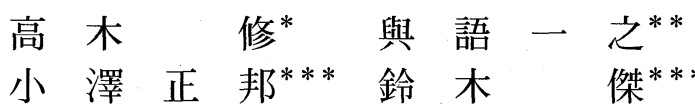

\section{Dispersion of Concentrated Alumina Aqueous Slurry}

by

\author{
Osamu TAKAGI ${ }^{*}$, Kazuyuki Yogo ${ }^{* *}$, Masakuni OzAWA ${ }^{* * *}$ and Suguru SuzukI ${ }^{* * *}$
}

\begin{abstract}
The particle dispersion in concentrated alumina aqueous slurry was investigated from colloidal vibration potential (CVP) and viscosity. In the present work, the CVPs of the slurry (40mass\%) were measured by an ultra-sonic vibration method as a function of $\mathrm{pH}$ and the concentration of organic dispersants, and viscosities were measured with a rotating cylinder viscometer for the slullies containing $0.04-4$ mass $\%$ dispersant at $\mathrm{pH} 7$. The CVP shifted to negative potential side with both increases in $\mathrm{pH}$ and the concentrain of dispersant in the range of $0.04-2 \mathrm{mass} \%$. The minimum viscosity appeared at with 2 mass\% dispersant. Moreover, it was found by an elemental analysis that the surface of alumina particles were saturated with dispersant molecules at about 2 mass\%. From the above mentioned, the CVP measurement thought to be effective in evaluating the particle dispersion in the concentrated alumina aqueous slurry.
\end{abstract}

Key words : Colloidal vibration potential, Viscosity, $\zeta$-potential, Isoelectric points, Aqueous ceramics slurry

\section{1 緒言}

粒子表面の荷電状態を知ることは，スラリー中での粒 子の分散，凝集状態を説明する上で非常に有意である. そして, 高濃度セラミックススラリーのコロイド振動電 位 (CVP : Colloidal Vibration Potential) ${ }^{1}$ を測定するこ とは，粒子表面の荷電状態を調べるのに有効である，従 来, セラミックス粒子表面の荷電状態は, ゼータ電位と して測定されてきた。ゼータ電位の測定法は DLVO 理 論 ${ }^{2)}{ }^{3)}$ に基づいており，希薄濃度系で測定されている。 このゼータ電位は, 粒子の表面特性を知る上では極めて重 要であり, 多くの研究者により検討が行われてきた. ${ }^{4)}$ (6) しかし，鋳込み用のスラリーや機能性塗料を考えた場合 のセラミックスペーストなど, 実用的な高濃度分散系を 検討する際には, 各種の添加剤が粒子表面に吸着し，ま た溶液中にも各種の電解質成分が共存しており，ゼータ 電位測定時の分散条件とは明らかに異なっている. CVP または超音波振動電位（UVP：Ultrasonic Vibration Potential）と呼ばれる電位は, 超音波などによりコロイ ド粒子を振動させた時, デバイ効果 ${ }^{7)}{ }^{8)}$ により $1 / 2$ 波長 の位相に発生する電位差のことである。CVP とゼータ電 位との大きな違いは， $50 \%$ 以上の高濃度スラリーでも測 定可能であるため, 先に述べた実用的な分散系の状態で 多様な検討が出来ることである。一般的な分散・凝集の 評価方法としては，粒子の直接観察法として光学顕微鏡 法, STM 法 ${ }^{9)}$ AFM 法 ${ }^{9)}$ などがあり，物性測定による間 接的評価法としては, 沈降法, 光散乱法やレオロジー法 などがある，実用的な分散系スラリーの評価を行う場合，
粘度計やレオメーターで粘性を測定するレオメーター法 を用いることが多い。これは測定が容易であることと， 塗料などの分野では得られたパラメーターが，実際に必 要な特性と良い相関を示すためであると考えられる. ${ }^{10)}$ ス ラリーの分散性を調整する方法としては，分散剤の添加 が有効であることが知られている，分散剤のイオン性や 添加率, 粒子表面との親和性や, 分子量, 分子構造に由 来する粘性などによって粒子の分散性は，大きく変化す ることが考えられる。実際に市販されている水系高濃度 ペーストなどでは, 分散剤以外にも防かび剤や消泡剂, レベリング剂, 増粘剤などの実に様々な物質が添加され ており, 電解質濃度も高い.

そこで本研究では，水系高濃度スラリーの pH を酸性 側からアルカリ側へと変化させることで粒子表面の荷電 状態を変化させ，その中で分散剤の添加量を変化させて； スラリーの CVP を測定した. また, 分散剤の添加量を変 化させたときの粘性の変化を検討することで, 粘性の変 化から考えられるスラリーの分散性の変化と, 測定され た CVP から考察される分散状態の変化との関係を検討 したので報告する.

\section{$2 \cdot 1$ スラリーの調製}

本実験系では，粉体にアルミナ（住友化学工業(侏)製 AKP-50： $\alpha-\mathrm{Al}_{2} \mathrm{O}_{3}$, 純度 $99.99 \%$ 以上, 平均粒径 $0.2 \sim$ $0.3 \mu \mathrm{m}$, BET 比表面積 $10.4 \mathrm{~m}^{2} \cdot \mathrm{g}^{-1}$ ) を, 分散剤にはポリ カルボン酸アンモニウム塩（東亞合成(株)製 A-6114：分子 量約 10000）を用いた。スラリーは， $1 \mathrm{~mol} \cdot \mathrm{dm}^{-3}$ 塩化力

原稿受理 平成 13 年 8 月 28 日 Received Aug. 28, 2001

* 名古屋工業大学セラミックス基盤工学研究センター †507-0071 多治見市旭ヶ丘, Ceramics Res. Lab., Nagoya Inst. of Tech., Asahigaoka, Tajimi, 507-0071

** 名古屋工業大学セラミックス基盤工学研究センター (現在 (株)成田製陶所) テ507-0071 多治見市旭ヶ丘, Ceramics Res. Lab., Nagoya Inst. of Tech., Asahigaoka, Tajimi, 507-0071

*** 正 会 員 名古屋工業大学セラミックス基盤工学研究センター †507-0071 多治見市旭ヶ丘, Ceramics Res. Lab., Nagoya Inst. of Tech., Asahigaoka, Tajimi, 507-0071 
リウム（和光純薬鉂製，試薬特級）水溶液に分散骫を添 加し，ホモミキサー (TOKUSHU KIKA製 T. K. AUTO HOMO MIXER) で溶液を十分かく找 (3000rpm, 2min.) しながらアルミナ粉末を添加混合して調製した，本実駼 は, 実用高濃度スラリーを考虑するため, 電解質濃度を通 常ゼータ電位の測定に用いられる電解質濃度よりも高く, 臨界凝集濃度（塩化カリウムの場合 $\left.0.02 \mathrm{~mol} \cdot \mathrm{dm}^{-3}\right)^{11}$ ) 以 上に添加して，故意に凝集系スラリーを作製し，それに 分散剤を添加することによって分散性を変化させた。 ス ラリー中のアルミナ固体濃度は，40mass\%に固定した。 分散剂の添加率は 0.4 ～4.0mass\% の範囲とした。

\section{$2 \cdot 2$ CVP 測定}

スラリーは, $1 \mathrm{~mol} \cdot \mathrm{dm}^{-3}$ 塩酸（和光純薬(株製，試薬 特級）を添加し, $\mathrm{pH}$ が $3 \sim 4$ で安定したものを初期状 態としてCVP 測定用ポットに用意した，次にポンプを用 いて，スラリーをポット下部から上部へ還流させ，また ポット底部にスターラーバーを入れてスラリーをかく汼 し，スラリー中のアルミナ粒子が沈殿しないようにした。 スラリーの $\mathrm{pH}$ は, $1 \mathrm{~mol} \cdot \mathrm{dm}^{-3}$ 水酸化カリウム（和光純 薬(森製，試薬特級）水溶液を還流中に徐々に添加するこ とにより調整した。

$$
\zeta=\frac{\mathrm{CVP} \times \lambda c \times \rho_{1} \times \eta}{\mathrm{P}_{1} \times 2 \phi(1-\phi)\left(\rho_{2}-\rho_{1}\right) \times \varepsilon_{0} \times D} \cdots
$$

$\zeta:$ ゼータ電位 $(\mathrm{mV})$

$\eta$ : 連続相の粘性 $\left(\mathrm{Ns} \cdot \mathrm{m}^{-2}\right)$

$P_{1}$ ：水中の音圧 $\left(\mathrm{N} \cdot \mathrm{m}^{-2}\right)$

$\lambda_{c}$ ：コロイド系の電気伝導度 $\left(\mathrm{S} \cdot \mathrm{m}^{-1}\right)$

$\phi:$ 体積濃度 $\left(\mathrm{kg} \cdot \mathrm{m}^{-3}\right)$

$\rho_{1}:$ 連続相の密度 $\left(\mathrm{kg} \cdot \mathrm{m}^{-3}\right)$

$\rho_{2}:$ コロイド相の密度 $\left(\mathrm{kg} \cdot \mathrm{m}^{-3}\right)$

$\varepsilon_{0}:$ 真空中の誘電率 $\left(\mathrm{C} \cdot \mathrm{N}^{-1} \cdot \mathrm{m}^{-2}\right)$

$D$ : 連続相の比誘電率

CVP の測定は超音波振動法 $(500 \mathrm{MHz})$ により PENKEM7000（PEN-KEM 社製）を用いて，測定した.ゼータ 電位と CVP の関係は式 (1)で関係付けられている.112), 13) 式 (1) からも分かるように, 粒子のゼータ電位が一定で あるならば，CVPはコロイド系の電気伝導度と粘性に反 比例する。

\section{$2 \cdot 3$ 粘性の測定}

CVP 測定スラリーの条件に合わせて，分散剤濃度を調 整したスラリーを用意し，二重円筒型粘弾性測定装置 （レオロジー社製：MR-500）を用いて剪断速度を 0 $210 \mathrm{~s}^{-1}$ の範囲で変化させ，せん断応力と粘性を測定した。

\section{$2 \cdot 4$ 組成分析}

CVP 測定スラリーの条件に合わせて $1 \mathrm{~mol} \cdot \mathrm{dm}^{-3}$ 塩化 カリウム溶液に分散剤抢よびアルミナ粒子を添加し，十 分混合させた後に $1 \mathrm{~mol} \cdot \mathrm{dm}^{-3}$ 塩酸打よび水酸化カリウ 么水溶液で $\mathrm{pH}$ を $4 ， 6 ， 8 ， 10$ に調整した。更に 12 時間 平衡化させた後に,メンブレンフィルター（ニトロセル ロース製，孔径 $0.10 \mu \mathrm{m} ）$ で吸引滤過し， $110^{\circ} \mathrm{C}, 8$ 時間 乾燥して粉末を得た。この粉末に対して蛍光 $\mathrm{X}$ 線組成分 析装置（理学侏製 M3270 型 SPECTROMETER）で，無 機組成分を分析し，有機元素分析装置（柳本製作所 CHN CORDER MT-5 型) で有機組成分 $(\mathrm{C}, \mathrm{H}, \mathrm{N})$ を分析 した.

\section{3 実験結果および考察}

レオメーターで測定した $\mathrm{pH} 7$ のスラリーへの分散剤添 加濃度と粘性の関係を Fig. 1 に示した。 四から，せん断 速度増とともに粘性が低くなる shear-thinning ${ }^{14)}$ 現象を 示していることが分かった．せん断速度の変化に対する せん断応力の変化を直線近似し，元の切片を降伏值とし て求めたものと分散剤添加濃度との関係を Fig. 2 に示し た. Hunterらによると降伏值が高いほど凝集体が存在す ることを示唆している. ${ }^{15,}{ }^{16)}$ Fig. 1 の結果と降伏値の変 化より, 分散剂添加濃度が $2 \mathrm{mass} \%$ の時に最も分散性が 良くなっていると考えられる。これらのことから，分散 剂添加濃度が $0.04 \mathrm{mass} \%$ から $2.00 \mathrm{mass} \%$ へ増加するに従 って分散性は向上するので分散剤は正常に機能していた と考えられる．また，分散剤が 4.00mass\%になるとスラ リーの状態は変化し, 分散状態は, むしろ低下したと考 えられる。この原因としては分散剤が過㮃であるための Depletion 凝集 ${ }^{17), 18)}$ と考元られる。.以上から, 分散剤濃 度が $2.00 \mathrm{mass} \%$ 以下の範囲で CVP と分散剤濃度の関係 を検討した。 その結果を Fig. 3 に示した.

分散剂濃度が低い $0.04 \mathrm{mass} \%$ の場合，スラリーの $\mathrm{pH}$

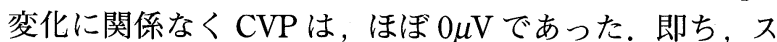

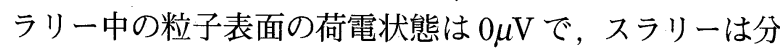
散性が悪く, 凝集しやすい状態と考えられる。分散剤濃 度が $0.20 \mathrm{mass} \%$ になるとスラリーが中性からアルカリ側 の範囲で CVP は僅かに負を示した，このことから，この $\mathrm{pH}$ の範囲でスラリーは多少分散しやすくなっていると考 えられる。更に分散剤添加濃度が $0.80 \mathrm{mass} \%$ 以上では $\mathrm{CVP}$ は $\mathrm{pH} 4$ 付近で $0 \mu \mathrm{V}$ となり，スラリーがアルカリ側

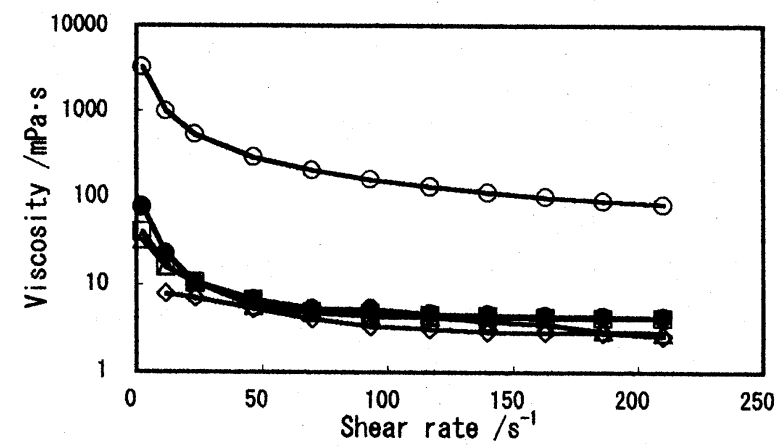

Fig. 1. Viscosity as a function of shear rate at $\mathrm{pH} 7$.

$\multimap 0.04$ mass\% $\multimap 0.40$ mass\% -0.80 mass\% -2.00 mass\% -4.00 mass\%

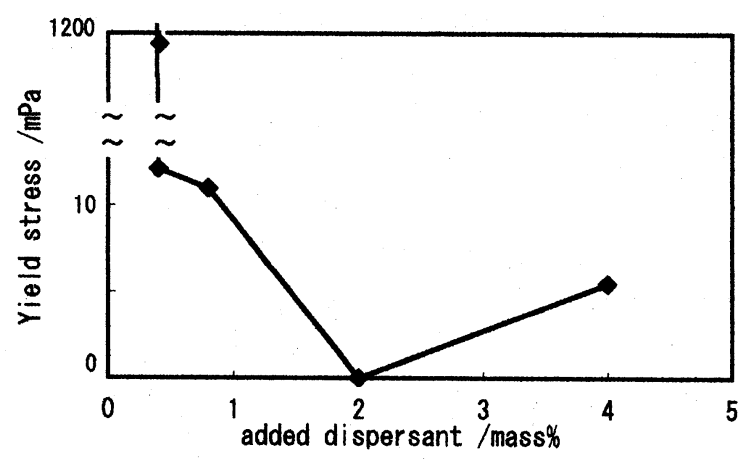

Fig. 2. Relation between added dispersant and yield stress at $\mathrm{pH} 7$. 


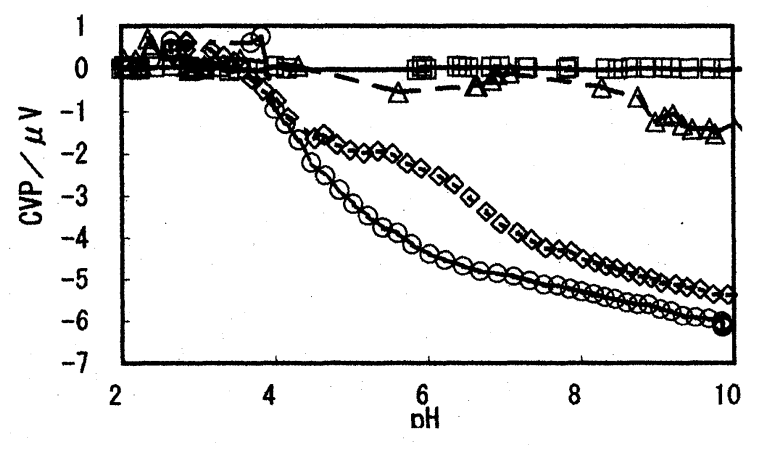

Fig. 3. CVP of slurry added with dispersant from 0.04 to $2.00 \mathrm{mass} \%$

$\rightarrow-0.04 \mathrm{mass} \% \rightarrow-0.20 \mathrm{mass} \% \rightarrow-0.80 \mathrm{mass} \% \rightarrow-2.00 \mathrm{mass} \%$

になると，大きく負の方向へ移行した．更に分散剤濃度 が $2.00 \mathrm{mass} \%$ になると同様に $\mathrm{pH} 4$ 付近で CVP は $0 \mu \mathrm{V}$ に なり，スラリーがアルカリ側になると，CVP は更に大き な負の方向にシフトした．分散剤添加濃度が $2.00 \mathrm{mass} \%$ 以下の範囲では，分散剤濃度の増加にともなって CVP 值 は $\mathrm{pH}$ が大きくなるに従って負の值が大きくなる傾向を 示したことから，スラリー中での粒子間の反発力が大き くなったと考えられ，アルカリ領域で分散性は向上した と思われる。

今回得られた CVPは，分散剂添加濃度の変化に関係 なく全てのスラリーで, $\mathrm{pH} 4$ 付近で 0 になっていると考 えた。式 (1) より， $\mathrm{CVP}=0$ の場合，ゼータ電位は 0 と なる。このゼータ電位が 0 となる点は等電点 (i. e. p.: isoelectric point) といわれており，粒子に固有の値とさ れている. ${ }^{4)}$ アルミナ粒子の等電点は $\mathrm{pH} 9$ 付近 ${ }^{19)}$ とされて おり，本研究の結果とは異なった。これは前述のように 今回はアルミナ粒子の表面に分散剤や電解質成分が特異 吸着された粒子が分散，流動の基本粒子になっていたた め, 純粋なアルミナ粒子の等電点と異なる粒子を測定し ていると考学られる。而, 20), 21)従って, 今回測定した高濃 度スラリーでの分散粒子の表面状態を調べることで，実 用高濃度スラリーの分散性と粒子の状態の関係を把握で きるものと考えた。 まず，アルミナスラリーに添加した 分散骭の効果については以下のように考えられる。

有機元素分析結果より, アルミナ粒子に吸着した分散 剤含有率を算出した結果を Fig. 4 に示した. 分散剤の粒 子表面への吸着率は, 分散剂含有率が $0.04 \sim 0.8 \mathrm{mass} \%$ までは, ほぼ添加量が粒子の表面に吸着しているが, 添 加率が 2.0 mass \% 以上になると溶液中に未吸着の分散剤 が存在し，増加する傾向にあると思われる。この結果か ら, 粉体に吸着する分散片の量は $0.8 \sim 2.0 \mathrm{mass} \%$ でほ ぼ飽和しており，穴れ以上に添加された分散㥔の吸着と は異なった機構によるものと考えられる。この吸着型は $\mathrm{BDDT}^{11)}$ の分類によると II 型の吸着等温線であると考え られる。 II 型の吸着等温線は, 非多孔性の固体上で多分 子層吸着が起こるときに得られる型 ${ }^{11)}$ と考えられている. 即ち, 分散剤添加濃度が $2.0 \mathrm{mass} \%$ 付近までは分散剤は アルミナ粒子の第 1 層目として吸着し, 分散剤濃度が $2.0 \mathrm{mass} \%$ 以上では飽和した分散㓮が第 2 層目として吸着 している. 第 2 層目の吸着が起こる分散剤濃度の場合, 未吸着の分散剂が分散媒側に多量に残るので, Fig. 2 の

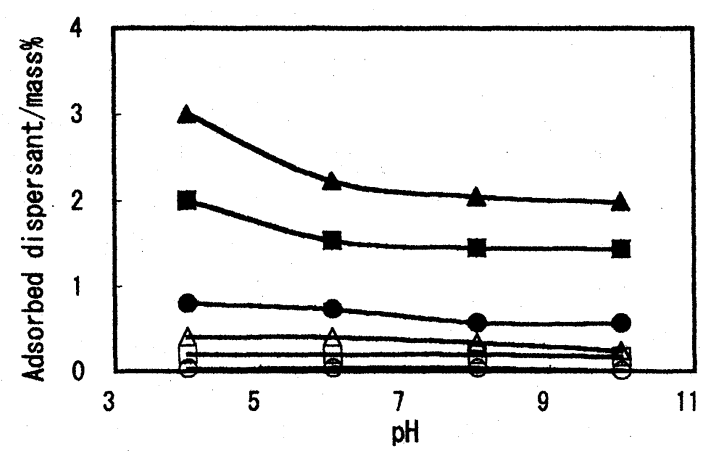

Fig. 4. Relation between $\mathrm{pH}$ and adsorbed dispersant.

$-0.04 \multimap 0.20 \multimap 0.40 \multimap 0.80 \rightarrow 2.00 \multimap 4.00$

分散剂添加濃度を $4.0 \mathrm{mass} \%$ にした場合の粘性の増加が， Depletion 凝集が原因であるとした考察と一致した. CVP の変化に関しては, 次のように考元られる.アルミナ濃 度 $2 \mathrm{mass} \%$ の低濃度スラリーでも, 分散剂にポリカルボ ン酸アンモニウム塩 $1 \mathrm{mass} \%$ を用いた系で同様に等電点 が $\mathrm{pH} 4$ 付近となるゼータ電位を示す結果が報告 ${ }^{6}$ されれて いる.この結果はアルミナ粒子の表面電位の影響よりも 粒子表面に吸着している分散剤などの影響が大きいと考 えられる。分散剤として使用しているポリカルボン酸ア ンモニウム塩の官能基であるカルボキシル基が $\mathrm{pH} 4$ 付近 から酸性側では非解離状態にあり, 粒子に対して Helix 構造 ${ }^{22)}$, 23)をとって吸着していると考えられる。また $\mathrm{pH} 6$ 付近よりアルカリ側ではカルボキシル基は解離状態 にあり，分散剤は粒子に対して延びた streched ${ }^{22), 23)}$ 状 態で吸着していると考えられ，この官能基に対するカウ ンターイオンとしての $\mathrm{H}^{+}$が表面電位を決定していると 考えられる. pH4での Helix 構造での吸着に関しては, 分散剤の吸着量が, 中性からアルカリ側での吸着量に比 較して僅かではあるが多いことからも示唆される. ${ }^{22)}$ 更に， Table Iに分散剂を 4.0 mass\% 添加した場合の $\mathrm{pH}$ の変化 に対する分散剩中の窒素・炭素比 $(\mathrm{N} / \mathrm{C})$ を示した. $\mathrm{pH} 4$ 〜8では, N/C は, ほぼ一定であり, 分散剤の化学的組 成は変化していないと考えられる.しかし， pH 10 では， スラリー調製段階でアンモニア臭が発生し，また分析結 果でも窒素がほぼ 0 になって打り, 分散媒中のアンモニ ウムイオンが非解離状態となって気体に変化したと考え られる。これらのことから，スラリー中の化学組成は, $\mathrm{pH} 10$ 以上では異なった状態になっていると考えられる. 次に，粒子表面に吸着された無機成分については以下の ように考えられる。分散剤濃度 $2.00 \mathrm{mass} \%$ スラリーの場 合のアルミナ粒子に吸着した $\mathrm{K}$ と $\mathrm{Cl}$ 量について, $\mathrm{pH} の$ 変化に対する $\mathrm{K} / \mathrm{Al}$ と $\mathrm{Cl} / \mathrm{Al}$ のモル比の関係を Fig. 5 に 示した。この結果から, 水酸化カリウムを添加してスラ

Table I. N/C ratio of power added with 4.0 mass\% dispersant.

\begin{tabular}{|c|c|c|}
\hline $\mathrm{pH}$ & $\mathrm{N} / \mathrm{C}$ & (mol ratio) \\
\hline 4 & & 0.08 \\
\hline 6 & & 0.09 \\
\hline 8 & & 0.08 \\
\hline 10 & & 0.00 \\
\hline
\end{tabular}




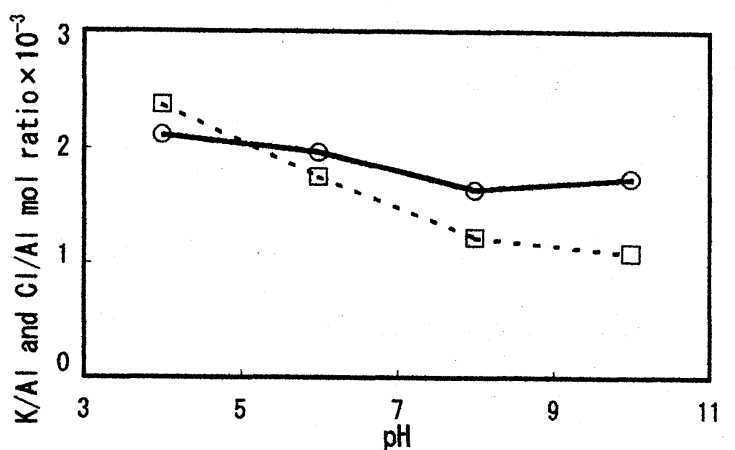

Fig. 5. Relation between $\mathrm{K} / \mathrm{Al}$ ratios and $\mathrm{pH}$.

$\theta-\mathrm{K} / \mathrm{Al} \cdot-\mathrm{G}-\mathrm{Cl} / \mathrm{Al}$

リーの $\mathrm{pH}$ をアルカリ側にシフトさせた場合, $\mathrm{pH} 4$ では カリウムの吸着率は塩素よりも少なかったが, $\mathrm{pH} 6$ から アルカリ側ではカリウムの吸着率は塩素吸着率よりも逆 転して多くなっていることが分った．先ほどの分散剤の 解離度と CVP の関係より $\mathrm{pH} 6$ よりもアルカリ側ではカ ルボキシル基が解離していることから, 高濃度の電解質 成分の内, カリウムの一部は, 分散剂による表面電位を 中和させる作用に寄与していると考えられる。このこと はFig. 3 において, 分散剂添加濃度が $0.20 \mathrm{mass} \%$ 以下 と低い場合には, $\mathrm{pH}$ の変化に関わりなく $\mathrm{CVP}$ が $0 \mu \mathrm{V}$ 付 近であることからも示唆された。即ち，分散剤濃度 $0.20 \mathrm{mass} \%$ となる表面電位を中和するに十分な電解質が 存在していると考えられる.

最後に高濃度スラリーの CVP と粘性の関係について 調べてみる. pH7 の状態で分散剤添加濃度を変化させた 場合の, スラリーの CVP の変化と降伏值の変化を Fig. 6 に示した.この結果より分散性の度合いを降伏值で代表 するとするならば, 高濃度スラリーにおいて CVP はスラ リーの分散性と良い相関関係にあると考えられる. CVP 測定は高濃度スラリーの分散性の検討に有効であると考 えられる。

\section{4 ま と め}

アルミナ粒子を用いた水系高濃度スラリーにおいて，分 散剤の添加濃度を変化させ, スラリーの分散性を CVP と 粘性により検討した結果, 以下のことが明らかとなった.

(1) 高濃度スラリーの CVP の等電点 (i. e. p.) は pH4 付近であり, 分散剤添加濃度が $0.04 \sim 2.00 \mathrm{mass} \%$ の範

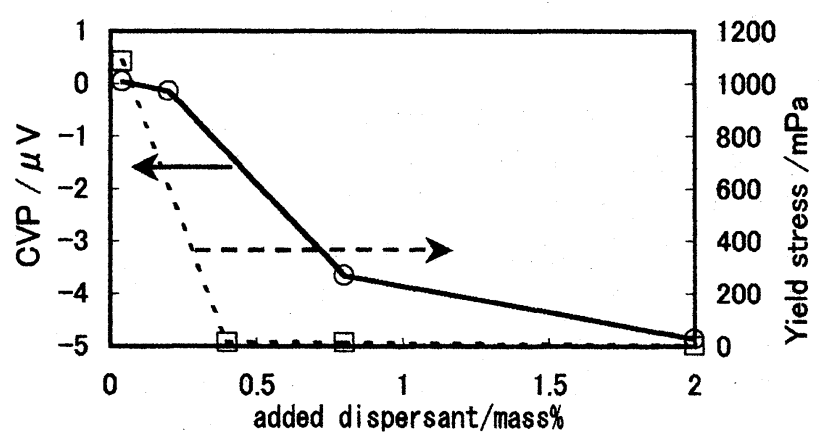

Fig. 6. Relation between added dispersant and CVP and yield stress at $\mathrm{pH} 7$.

-CVP $\quad-$ - -Yield stress
囲では, 分散剤濃度が高くなると CVP 值は $\mathrm{pH}>4$ 領域で 負に大きくシフトした.

（2）分散剤濃度が 2.00 mass\% で粘性が最も低くなり， ニュートン粘性流動を示していることから分散性が最も 向上していることが分った.

（3） ポリカルボン酸アンモニウム塩を分散剤として用 いた場合, 表面電位を決定するのはカルボキシル基に対 する $\mathrm{H}^{+}$であり, 中性からアルカリ域ではカルボキシル基 が解離状態となる為, 粒子は負に帯電すると考えられる.

(4) 高濃度電解質系では, 分散剤添加濃度が低い場 合, 電解質成分の中和作用により CVP が $0 \mu \mathrm{V}$ に近くな つた。

(5) 高濃度アルミナスラリーにおいて, 分散剤添加濃 度を変化させてスラリー中のアルミナの分散性を変化さ せた場合, CVP 值の変化と粘性（降伏值）による分散性 の評価は良く一致しており, CVPの測定は，スラリーの 分散性を評価する上で, 非常に有意であることが分った。

\section{参 考 文 献}

1) J. A. Enderby, Proc.Phys. Soc., 207A, 321 (1951).

2) B. V. Derjaguin and L. Landau, Acta Physicochim., URSS, 14, 633 (1941).

3 ) E. J. W. Verwey and J. Th G Overbeek, Theory of the Stability of Lyophobic Colloids, 193 (1948).

4 ）北原文雄, 渡辺 昌編 “界面電気現象”, p.164 (1983) 共 立出版.

5) A. Kitahara and A. Watanabe Eds, Electrical Phenomena at Interfaces (Marcel Dekker), 169 (1984).

6) 柳 炳煥, 高橋 実, 鈴木 傑, J. Ceram. Soc. Jap., 101 [6], 643 (1993).

7) 神保元二, 小沢英一, 向阪保雄, 小宮山宏, 定方正毅, 吉沢昭宣, “微粒子ハンドブック”, p.69（1991）朝倉書 店.

8) P. Debye, J. Chem. Phys., 1, 13 (1933).

9) G. Binnig and H. Rohrer; Rev. Mod Phys., 50, 615 (1987).

10） T. C. Patton, “塗料の流動と顔料分散” (1971) 共立出版.

11) S. Brunauer, L. S. Deming, W. E. Deming and E. Teller, J. Amer. Chem. Soc., 62, 1723 (1940).

12) B. J. Marlow, D. Fairhurst and H. P. Pendse, Langmuir, 4, 611 (1988).

13) Wo. Ostwald, Koll. Z., 36, 99 (1925).

14) B. A. Firth and R. J. Hunter, J. Colloid Sci., 57, 248 (1976).

15) R. J. Hunter and J. Frayne, J. ColloidSci., 71, 30 (1979).

16) D. H. Napper, "Polymeric Stabilization of Colloidal Dispersion", p.413 (1983) Academic Press, London.

17) S. Asakura and F. Osawa, J. Chem. Phys., 22, 1255 (1954).

18) G. A. Parks, Chem. Rev., 65, 77 (1965).

19) J. Th. G. Overbeek, Pure Apple. Chem., 52, 1151 (1980).

20) O. Stern, Z. Elektrochem., 30, 508 (1924).

21) S. Levine, G. Neale and N. Epstein, J. Colloid Interface Sci., 57, 424 (1976).

22）北原文雄, 古澤邦夫, 尾崎正孝, 大島広行 “ゼー夕電位”, p.126（1995）サイエンティスト社.

23) K. Furusawa, M. Kanesaki and S. Yamashita, J. Colloid Interface Sci., 99, 341 (1984). 